\title{
Anaphylaxis by inhalation of allergenic proteins from Anisakis simplex
}

\author{
Dalhila Janett Garcia Navarro ${ }^{1 *}$, Ana Montoro De Francisco², Tomas Chivato Perez², \\ Francisco Javier Membrillo De Novales ${ }^{3}$, Maria Angeles Nuñez Hernandez ${ }^{2}$, Belen De Mateo Hernandez ${ }^{2}$, \\ Manuel Fernandez Lopez ${ }^{2}$, Jose Maria Mateos Galvan² \\ From 9th Symposium of Experimental Rhinology and Immunology of the Nose (SERIN 2013) \\ Leuven, Belgium. 21-23 March 2013
}

\section{Background}

Anaphylaxis can affect $20 \%$ of patients sensitized to Anisakis simplex. There have been reports of occupational asthma due to inhalation of allergens in patients who handle raw fish. Anisakis has several proteins which are capable of producing sensitations, primarily by ingestion, but may also occur through contact or inhalation.

\section{Method}

We report a 50 year old patient, who works as a cook. A year ago she presented two episodes of anaphylaxis after eating undercooked fresh fish. Thereafter she removed raw fish from her diet. Ten months later after handling fish (eviscerating it), an hour after hand injuring, she presented itching hands and head, epigastric pain, nausea and severe generalized urticaria. Attended the emergency room with adrenaline, corticosteroids, antihistamines, with good response. She manipulates fish daily with gloves because of her profession. Prick test (PT) with allergenic extracts of fish, Anisakis, food (Alk Abelló).Total and specific IgE to Anisakis, white and blue fish (Thermo Fisher). Gastroscopy.

\section{Results}

Negative PT both raw and cooked whiting. Anisakis simplex PT positive both immediate and $48 \mathrm{~h}$ later reading. Allergic response test against aeroallergens negative. Total IgE $1821 \mathrm{KU} / \mathrm{l}$. Specific IgE levels were always kept high Anisakis:> 100KU / 1.Normal Gastroscopy: Anisakis larvae not observed. Not taking biopsy.

'Hospital Central de la Defensa "Gómez Ulla", Madrid, Spain

Full list of author information is available at the end of the article

\section{Conclusion}

We report a case of anaphylaxis following ingestion, contact and inhalation of various Anisakis simplex proteins in a patient previously sensitized by digestive tract. The positivity of tests carried out in vivo and in vitro against Anisakis with negativity against fish proteins, confirms the diagnosis of anaphylaxis by inhalation, because the patient had not returned to eating fish.

\section{Author details}

'Hospital Central de la Defensa "Gómez Ulla", Madrid, Spain. ${ }^{2}$ Hospital Central de la Defensa "Gómez Ulla", Allergy Department, Madrid, Spain. "Hospital Central de la Defensa "Gomez Ulla", Internal Medicine Department, Madrid, Spain.

Published: 16 July 2013

doi:10.1186/2045-7022-3-S2-P13

Cite this article as: Garcia Navarro et al: Anaphylaxis by inhalation of allergenic proteins from Anisakis simplex. Clinical and Translational Allergy 2013 3(Suppl 2):P13.

Submit your next manuscript to BioMed Central and take full advantage of:

- Convenient online submission

- Thorough peer review

- No space constraints or color figure charges

- Immediate publication on acceptance

- Inclusion in PubMed, CAS, Scopus and Google Scholar

- Research which is freely available for redistribution 